\title{
Analysis of Tumor Suppressor Gene p53 in Chicken Lymphoblastoid Tumor Cell Lines and Field Tumors
}

\author{
Michihiro TAKAGI, Kazuhiko OHASHI, Toshifumi MORIMURA, Chihiro SUGIMOTO and Misao ONUMA* \\ Laboratory of Infectious Diseases, Department of Disease Control, Graduate School of Veterinary Medicine, Hokkaido University, \\ Sapporo 060-0818, Japan
}

(Received 7 January 1998/Accepted 22 April 1998)

ABSTRACT. To determine whether there is any abnormalities of the $p 53$ gene in chicken lymphoblastoid tumor cell lines derived from Marek's disease (MD), lymphoid leukosis, reticuloendotheliosis, and field tumors, some portions of $p 53$ cDNA corresponding to core and C-terminal domains (nucleotide positions 277-1104 in the p53 open reading frame (ORF)) were sequenced. Several mutations were identified in both cell lines and field tumors. However, none of these mutations is localized at the "hot spot", which has been reported as the site for transformation-activating mutations. Moreover, partial cDNA clones with a 122-bp deletion in the $p 53$ ORF were identified in two cell lines, MSB1 and MTB1 derived from MD tumors. Southern blot analysis showed that no deletion occurred in the genome of $p 53$ in MSB1, indicating that deletion occurred at the transcriptional level. This deletion could cause a frame shift of the encoding p53 protein, possibly resulting in the generation of a functionally different p53 protein. However, we confirmed that p53 mRNA without deletion is also present in each of these cell lines. These mutations of the $p 53$ gene and deletion in the $p 53$ transcript may be ones of molecular changes specific to the transformation induced by MD virus. — KEY wORDS: Marek's disease, p53, RT-PCR, transformation.

J. Vet. Med.Sci. 60(8): 923-929, 1998

The tumor suppressor gene $p 53$ plays a role in mediating the cellular response to DNA damage caused by $\gamma$ irradiation, UV, drugs and viral transforming proteins [5, 14, 33]. p53 can act as a transcriptional regulator and transactivate cellular genes through sequence-specific interactions with DNA containing the sequence, 5'$\mathrm{PuPuPuC}(\mathrm{A} / \mathrm{T})(\mathrm{T} / \mathrm{A})$ GPyPyPy-3', typically in the context of two such sequence motifs separated by up to $13 \mathrm{bp}$ [4, 11]. At least two important biological pathway are regulated by 553 in connection with its function as a tumor suppressor. These are the induction cell cycle arrest at the G1 phase [10], and the induction of apoptosis [34].

The function of p53 is inactivated in many human and other mammalian tumors by several point mutations within the $p 53$ gene itself. Most of these point mutations, causing conformational changes, are associated with a loss of DNA binding ability of p53. On the other hand, viral oncoproteins, such as simian virus 40 large $\mathrm{T}$ antigen [15, 21], adenovirus type $5 \mathrm{E} 1 \mathrm{~B}$ protein [32], human papilloma virus type 16/18 E6 protein [24], and hepatitis B virus Xprotein [28], inactivated p53 through their formation of complexes with $\mathrm{p} 53$. The mutations and deletion of the $p 53$ gene have been found in many kinds of cancers in mammalian species [12, 16, 19].

Marek's disease virus (MDV) is a herpesvirus that causes a lymphoproliferative disease of chickens, which is characterized by malignant T-cell lymphoma and

* Correspondence to: Onuma, M., Laboratory of Infectious Diseases, Department of Disease Control, Graduate School of Veterinary Medicine, Hokkaido University, Sapporo 0600818, Japan. demyelination of peripheral nerves [23]. The molecular mechanism of transformation by MDV has not been fully understood. Unlike retroviruses, MDV does not have any apparent oncogenes, suggesting that interaction of viral proteins with cellular oncoproteins or activation of cellular oncogenes are important for the transformation mechanism. Recently, it has been reported that Meq, which has a homology with members of the jun/fos oncoprotein family, could be a viral oncogene based on its potential role as a transcription factor [30]. In addition, the Meq protein has been shown to have a potential to interact with p53 [2], suggesting possible involvement of this interaction in the transformation process by MDV. However, no information is available concerning the changes in the $p 53$ gene of host cells related to transformation by MDV. Thus, to determine whether $p 53$ mutations are involved in the neoplastic process of chicken lymphoma, we analyzed the molecular structure of chicken $p 53$ genes and its transcripts in chicken tumor cell lines derived from MD, avian leukosis (AL), reticuloendotheliosis (RE), and field tumors. We here reported that tumor cell lines possess mis-sense mutations and deletion in the p53 transcript.

\section{MATERIALS AND METHODS}

Cell lines and tumor samples: Ten chicken cell lines established from chicken lymphoma were used in this study, MD cell lines: MSB1 [1], MTB1 [9], JP1, JP2 [31], HP1, HP2 [20] and RP1[18]; AL cell lines: 1104B1 [6] and CU10 [3] an RE cell line: $\mathrm{Ku} 7$ [22]. All cell lines were grown at $40^{\circ} \mathrm{C}$ in RPMI1640 medium supplemented with $10 \%$ fetal bovine serum, penicillin $\mathrm{G}(200 \mathrm{U} / \mathrm{m} l)$, streptomycin $(200$ $\mathrm{mg} / \mathrm{ml}$ ) and $2 \times 10^{-5} \mathrm{M} 2$-mercaptoethanol. Tumor samples 
Table 1. Primers used to amplify chicken $p 53$ cDNA

\begin{tabular}{lllc}
\hline Primer & Nucleotide sequence & $\begin{array}{c}\text { Annealing temperature } \\
\left({ }^{\circ} \mathrm{C}\right)\end{array}$ & $\begin{array}{c}\text { Size of fragments } \\
\text { amplified (location) }\end{array}$ \\
\hline p53-5 & 5'-ATGTGCAACAGTTCCTGCAT-3' & 55 & $157 \mathrm{bp}$ \\
p53-6 & 5'-AGTTCTCCTCCTCGATCTTG-3' & & $(667-823)$ \\
p53-8 & 5'-AAAAGGGGGCGTCGTCAGT-3' & 50 & $680 \mathrm{bp}$ \\
p53-9 & 5'-GTCTATAAGAAATCAGAGCA-3' & & $(439-1119)$ \\
p53-11 & 5'-TGCTCTGATTTCTTATAGAC-3' & 46 & $182 \mathrm{bp}$ \\
p53-12 & 5'-GACTTCCGGGTGGGGTTCGT-3' & & $(277-458)$ \\
\hline
\end{tabular}

a) Numbers indicate the locations in the $p 53$ open reading frame.

were obtained from the spleens and livers of 5 chickens which showed clinical signs related to MD in a commercial poultry house. Tumor samples were also obtained from 2 chickens purchased from Hokuren Co., Ltd., Sapporo, which were experimentally infected with a very virulent MDV, strain Md5, in our laboratory.

Preparation of total cellular RNA: Total RNA was isolated from cell lines and tumor samples using TRIzol (GIBCO-BRL, Gaitherburg, MD) following the manufacturer's instructions.

Reverse transcription and polymerase chain reaction: Extracted total cellular RNA $(10 \mu \mathrm{g})$ treated with DNaseI (Boehringer Mannheim GmbH, Germany) was dissolved in $30 \mu l$ of reaction buffer containing $50 \mathrm{mM}$ Tris- $\mathrm{HCl}(\mathrm{pH} 8.3)$, $40 \mathrm{mM} \mathrm{KCl}, 1 \mathrm{mM}$ DTT, $3 \mathrm{mM} \mathrm{MgCl}_{2}, 0.5 \mathrm{mM}$ each of dATP, dCTP, dGTP and dTTP, $40 \mathrm{U}$ of RNase inhibitor (Promega, Madison, WI, U.S.A.), 200 pmol Oligo (dT) $)_{15}$ and $20 \mathrm{U}$ of reverse transcriptase (RAV-2, Takara, Kyoto, Japan). The mixture was incubated at $42^{\circ} \mathrm{C}$ for $60 \mathrm{~min}$ for reverse transcription. Then, newly synthesized first strand cDNA $(30 \mu l)$ was mixed with $70 \mu l$ of distilled water. For polymerase chain reaction (PCR), $10 \mu l$ of cDNA template was added to $40 \mu \mathrm{l}$ of reaction buffer containing $20 \mathrm{mM}$ Tris- $\mathrm{HCl}$ ( $\mathrm{pH} 8.4$ ), $50 \mathrm{mM} \mathrm{KCl}, 1.5 \mathrm{mM} \mathrm{MgCl} 2,0.8 \mathrm{mM}$ each of dATP, dCTP, dGTP and dTTP, 30 pmol sense/ antisense primers (Table 1, Fig. 1A) designed from the previously reported chicken $p 53$ cDNA sequence [26], and $2.5 \mathrm{U}$ of Taq polymerase (Pharmacia Biotech, Uppsala, Sweden). The PCR were performed on a thermal cycler (PTC-100, MJ Research, Watertown, MA) under the following conditions: one cycle of $4 \mathrm{~min}$ at $94^{\circ} \mathrm{C}$, followed by 35 cycles of $1 \mathrm{~min}$ at $94^{\circ} \mathrm{C}, 1.5 \mathrm{~min}$ at 46,48 or $55^{\circ} \mathrm{C}$, and $1.5 \mathrm{~min}$ at $72^{\circ} \mathrm{C}$, and a final $72^{\circ} \mathrm{C} 10 \mathrm{~min}$ extension cycle. The PCR products $(10 \mu l)$ were separated on $2 \%$ agarose gels and visualized by staining with ethidium bromide.

DNA sequencing: The PCR products were purified by using Geneclean II kit (Bio 101, La Jolla, CA) and cloned into pGEM-T vector (Promega Corp., Madison, WI). Cloned inserts were sequenced on a $373 \mathrm{~A}$ automatic sequencer (Applied Biosystems, Foster City, CA) using the Taq dye terminator cycle sequencing kit (Perkin-Elmer, Foster City, CA).

Northern blot analysis: For the detection of p53 mRNA, total cellular RNA ( $15 \mu \mathrm{g}$ ) from tumor cell lines and normal spleen were fractionated on a $1.5 \%$ agarose gel containing $1 \%$ formaldehyde in MOPS buffer, transferred to a nylon membrane filter, (Hibond-N+, Amersham, Buckinghamshire, UK), and hybridized with ${ }^{32} \mathrm{P}$-labeled a NcoI-NdeI fragment of p53/8-9 cDNA in hybridization buffer (5XSSC, 5XDenhardt's reagent, 0.5\% SDS, 50\% formamide) at $42^{\circ} \mathrm{C}$ for overnight. The filter wes washed twice with $2 \mathrm{XSSC} / 0.1 \% \mathrm{SDS}$ at room temperature, three times with $0.1 \mathrm{XSSC} / 0.1 \% \mathrm{SDS}$ at $65^{\circ} \mathrm{C}$, and subjected to autoradiography.

Isolation of DNA and Southern blot analysis: High molecular weight genomic DNA was isolated from normal spleen and MSB1. Cells were lysed in lysis buffer $(20 \mathrm{mM}$ Tris- $\mathrm{HCl}, 25 \mathrm{mM}$ EDTA, $100 \mathrm{mM} \mathrm{NaCl}, 0.5 \%$ SDS, pH 8.0) containing proteinase $\mathrm{K}(1 \mathrm{mg} / \mathrm{m} l)$ for overnight at room temperature. The lysate was extracted with phenol and chloroform, then DNA was precipitated with ethanol. Approximately $10 \mu \mathrm{g}$ of genomic DNA was digested with EcoRI, BamHI, or PstI, fractionated on a $0.8 \%$ agarose gel, and transferred to a nylon membrane filter. The filter was hybridized with p53/8-9 cDNA probe in buffer $(0.5 \mathrm{M}$ Sodium-pyrophosphate buffer, $1 \mathrm{mM}$ EDTA, 7\% SDS, pH 7.2) at $65^{\circ} \mathrm{C}$ for overnight. The filter was washed in washing buffer (40 mM Sodium-pyrophosphate buffer, $1 \%$ SDS, pH 7.2) at $65^{\circ} \mathrm{C}$, and subjected to autoradiography.

\section{RESULTS}

PCR and DNA sequencing: PCR amplification of cDNA prepared from all cell lines, tumor samples, normal spleen as a control, using primer pairs p53-5 and p53-6, p53-11 and p53-12 resulted in production of 157-bp and 182-bp cDNA fragments, respectively (Fig. 1). By using p53-8 and p53-9 primers, a 681-bp band was detected in tumor samples, normal spleen and all examined tumor cell lines except for MSB1 and MTB1. Instead, a approximately 600bp fragment was amplified from MSB1 and MTB1 (Fig. 1).

In the next experiment, we determined if the p53 transcripts from these chicken cell lines and tumor samples had any mutations (Table 2). The nucleotide sequences of these amplified DNA fragments of $p 53$ cDNA corresponding to the positions 277 to 1119 in the $p 53$ open reading frame from all cell lines, tumor samples and normal spleen were compared with that of chicken wild-type $p 53$ cDNA reported previously. Mutations were found in 9 out of 10 cell lines 
$\mathbf{A}$

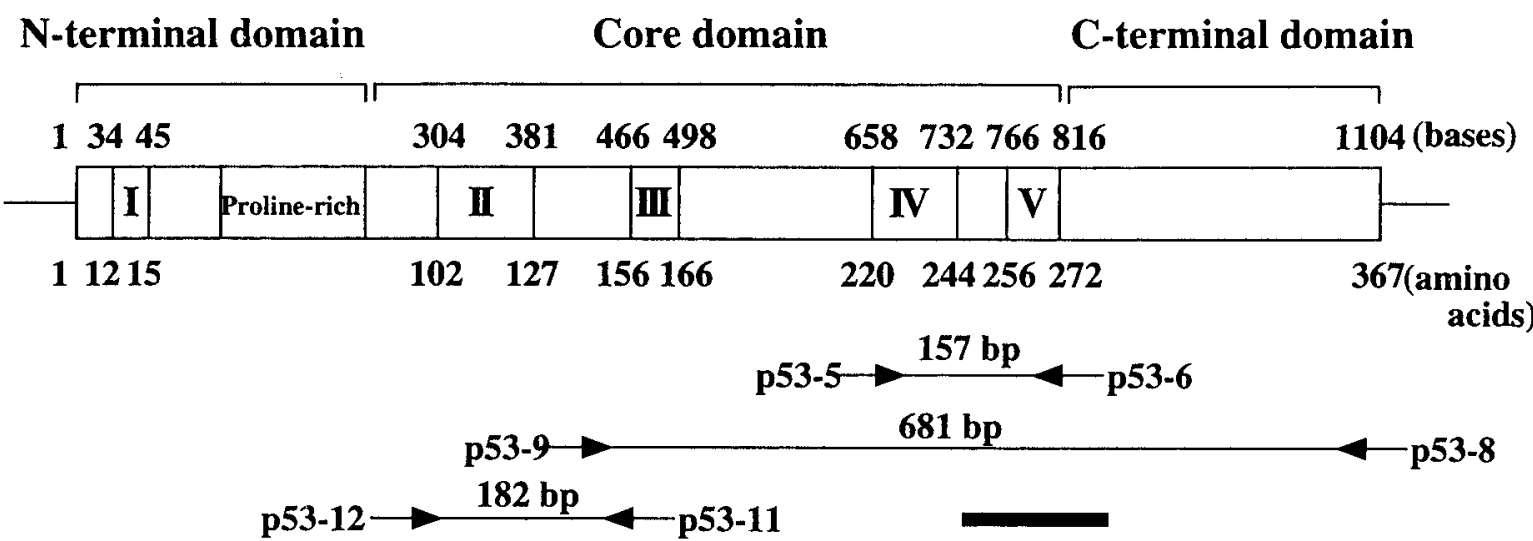

122-bp deletion
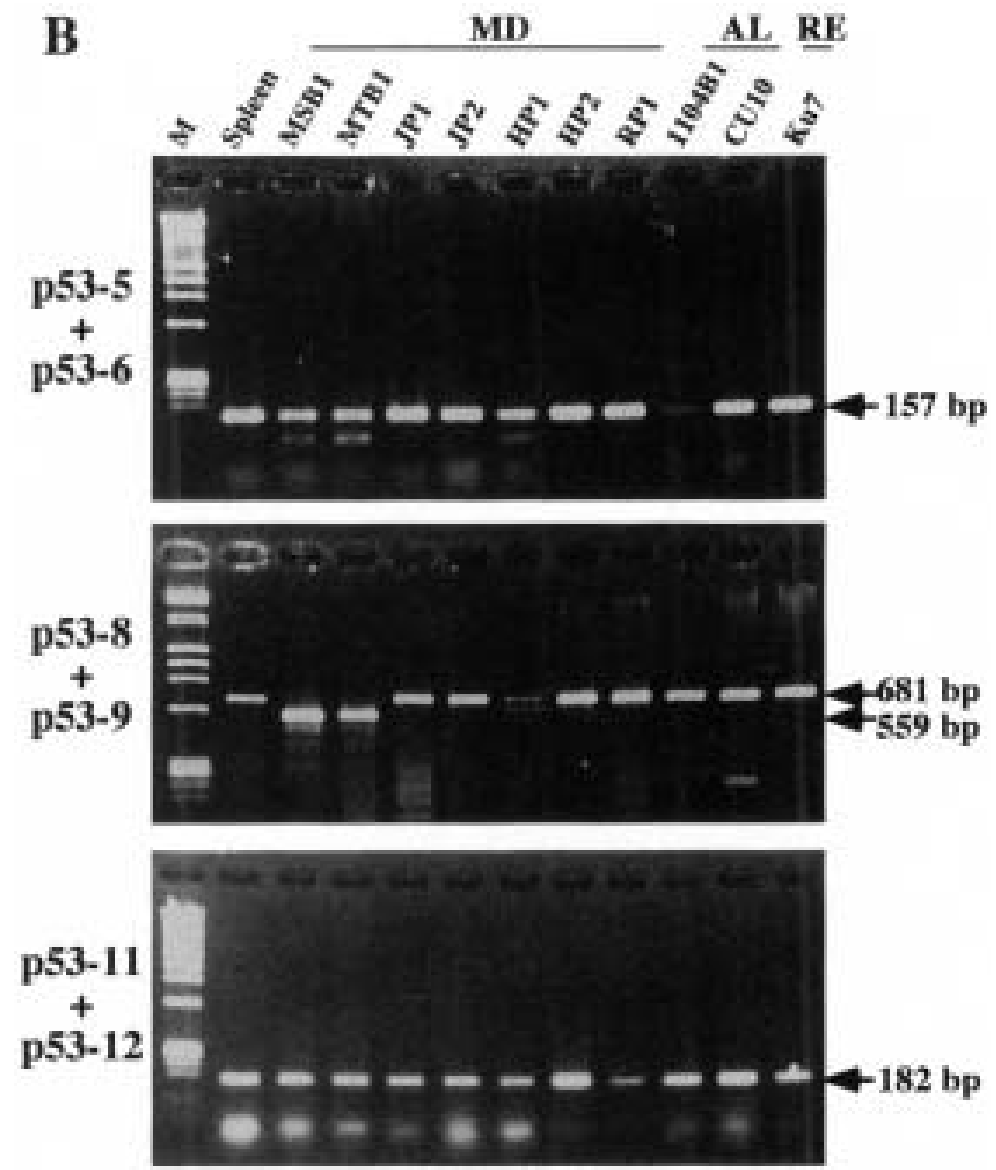

Fig. 1. (A) Schematic representation of the $p 53$ open reading frame and locations of primers used in RT-PCR. PCR was performed by using three different pairs of $p 53$-specific primers (Table 1). Highly conserved regions are indicated with roman numbers, I, II, III, IV and V, and positions of these domains are indicated with both nucleotide and codon numbers. (B) RTPCR of p53 transcripts expressed in chicken tumor cell lines. RNA samples were prepared from Marek's disease (MD), avian leukosis (AL) and reticuloendotheliosis (RE) tumor cell lines, and normal spleen as a control. Resultant PCR products were resolved on the agarose gel, and analyzed by ethidium bromide-staining. Arrows indicate the positions of the amplified $p 53$ specific products. 
Table 2. Mutations of p53 genes in chicken lymphoblastoid cell lines and tumor samples

\begin{tabular}{ccccc}
\hline \multirow{2}{*}{$\begin{array}{c}\text { Cell line and } \\
\text { tumor sample }\end{array}$} & Origin & \multicolumn{4}{c}{ Mutation analysis } \\
\cline { 3 - 5 } & Codon & Nucleotide & Amino acid \\
\hline MSB1 & MD & 146 & GCC $\rightarrow$ GTC & Alanine $\rightarrow$ Valine \\
MTB1 & MD & 188 & CAG $\rightarrow$ CCG & Glutamine $\rightarrow$ Proline \\
& & 202 & GTC $\rightarrow$ CTC & Valine $\rightarrow$ Leucine \\
JP1 & MD & 146 & GCC $\rightarrow$ GTC & Aline $\rightarrow$ Valine \\
JP2 & MD & 253 & CGG $\rightarrow$ TGG & Arginine $\rightarrow$ Tryptophan \\
HP1 & MD & 146 & GCC $\rightarrow$ GTC & Alanine $\rightarrow$ Valine \\
RP1 & MD & & ND & \\
1104B1 & AL & 146 & GCC $\rightarrow$ GTC & Alanine $\rightarrow$ Valine \\
CU10 & AL & 146 & GCC $\rightarrow$ GTC & Alanine $\rightarrow$ Valine \\
KU7 & RE & 146 & GCC $\rightarrow$ GTC & Alanine $\rightarrow$ Valine \\
& & 356 & AGG $\rightarrow$ ATC & Serine $\rightarrow$ Isoleucine \\
G1 & spleen & 146 & GCC $\rightarrow$ GTC & Alanine $\rightarrow$ Valine \\
G2 & liver & & ND & \\
G3 & spleen & & ND & \\
G4 & spleen & & ND & \\
G5 & spleen & & ND & \\
H1 & spleen & & ND & \\
H2 & spleen & & ND & \\
\hline
\end{tabular}

Tumor samples G1 to G5 were obtained from 5 chickens in a commercial poultry house, and $\mathrm{H} 1$ and $\mathrm{H} 2$ were obtained from chickens experimentally infected with MDV in our laboratory. ND, mutations were not detected.

and one out of 7 tumor samples examined. A nucleotide $\mathrm{C}$ to $\mathrm{T}$ transition in codon 146 was found for MSB1, JP1, HP1, HP2, 1104B1, CU10 and Ku7 cell lines and one field tumor sample (G1), and this codon was changed from alanine to valine. For $\mathrm{Ku} 7$, codon 356 was also changed from $\mathrm{G}$ to $\mathrm{T}$, resulting in transition of the codon from serine to isoleucine. Two-base-pair mutations were identified in MTB1, which resulted in the substitutions of glutamine for proline at codon 188 (transition from CAG to CCG), of valine for leucine at codon 202 (transition from GTC to CTC). A transition from $\mathrm{C}$ to $\mathrm{T}$ occurred within codon 253 (CGG to TGG) in JP2, resulting in a change of the encoded amino acid from arginine to tryptophan.

A short form of p53 cDNA detected in MSB1 and MTB1: Since RT-PCR resulted in the amplification of a shorter $p 53$ cDNA fragment than wild-type cDNA in two MD cell lines, MSB1 and MTB1 (Fig. 1), the nucleotide sequences of the short forms were determined. These fragments were 559 bp in length, and the sequence encoding of the C-terminal part of the core domain including domain $\mathrm{V}$ was deleted (Fig. 2). This deletion could cause a frame shift, possibly generating a different p53 molecules consisting of 268 amino acids. However, random sequencing of the amplified fragments from MSB1 and MTB1 showed that the p53 transcript without deletion is also present in each of these cell lines although the 681-bp fragment was not visible by the staining with ethidium bromide (Fig. 1B). This short form of the $p 53$ transcript was not detected in tumor samples obtained from chickens in a commercial poultry house or from chickens experimentally infected with MDV.

Northern blot analysis: To determine whether two types of p53 mRNA were expressed in MSB1 and MTB1,
Northern blot analysis was performed (Fig. 3). A p53 transcript of $1.8 \mathrm{~kb}$ was found in all tested cell lines and normal spleen as a control. However, it was impossible to detect two types of p53 transcripts in MSB1 and MTB1 because they are only 122-base different from each other.

Southern blot analysis: To estimate whether genomic alterations related to $p 53$ gene expression occurred in the MSB1 cell line, Southern blot analysis was carried out (Fig. 4). The genomic DNA from normal spleen and MSB1, digested with EcoRI, BamHI and PstI, and probed with p53/ 8-9 cDNA, had a 4.2- kb, and 5.3- and 3.7- kb bands, respectively. Similar to the result of Northern blot analysis, no deletion was occurred in the p53 gene of MSB1.

\section{DISCUSSION}

Mutations in the $p 53$ gene has been shown in many kinds of mammalian tumors. These mutations were found within or around five conserved regions I, II, III, IV and V [26]. "Hot spots", in which mutations were frequently occurred, exist in these regions [7]. In this study, several mutations were found in ten cell lines derived from MD, AL and RE, and one field tumor sample (Table 2). However, these mutations were not localized at the "hot spots". These results suggested that mutations of the $p 53$ gene in chicken tumors may occur out of conserved regions, or that these mutations may not change the functional properties of $\mathrm{p} 53$.

It is of interest that a short form of p53 transcript was detected in MSB1 and MTB1 derived from MD. This short form was not detected in cell lines from $\mathrm{AL}$ and $\mathrm{RE}$, suggesting that the presence of the short form of the $p 53$ transcript may be one of molecular changes specific to MDV 

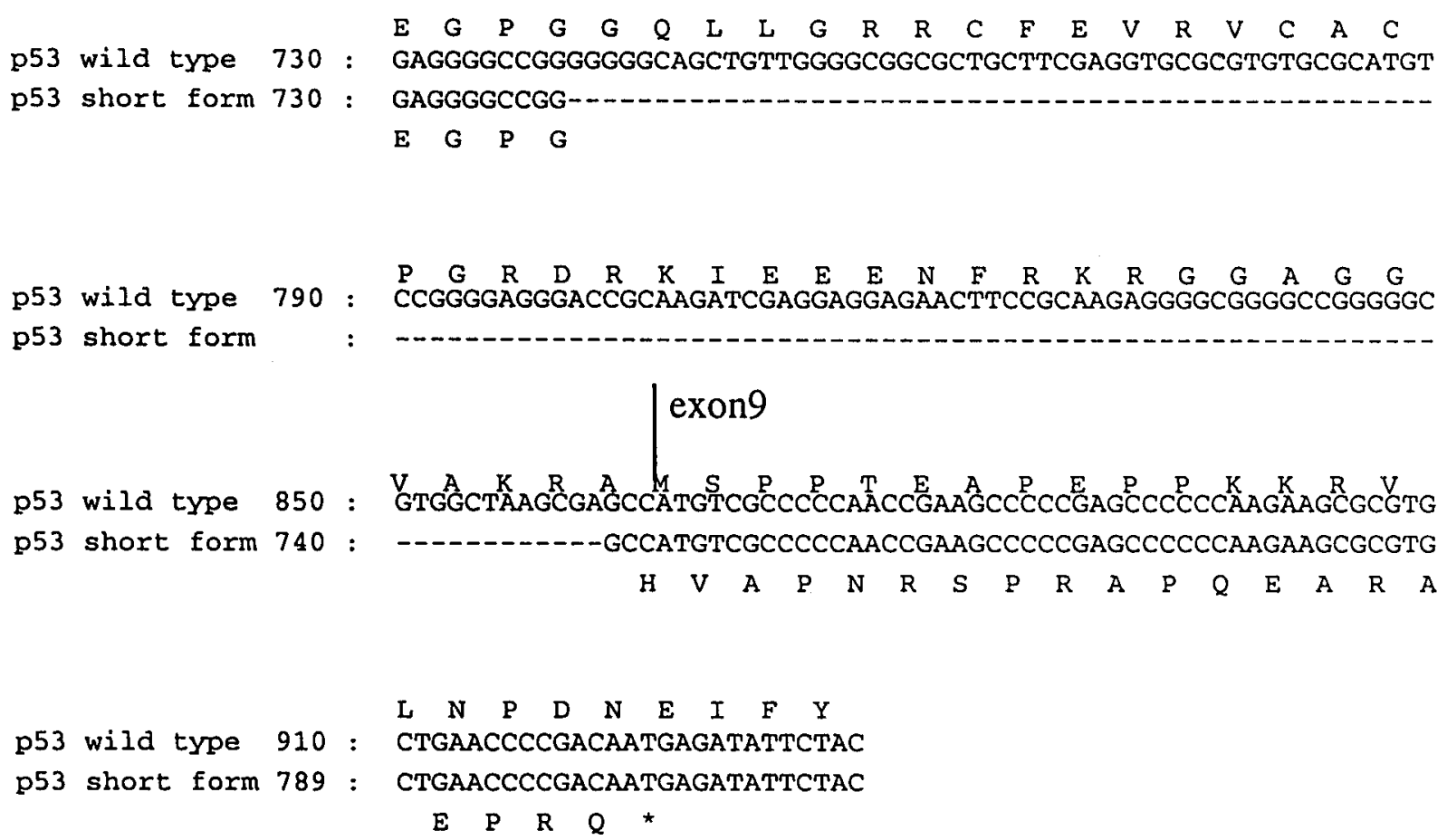

Fig. 2. Comparison of the nucleotide sequences between the wild type and short form of $p 53$ cDNA. Nucleotide sequences corresponding a part of exons 8 and 9 and deduced amino acid sequences are shown. Dashes (-) represent the deleted sequence in the short form of $p 53 \mathrm{cDNA}$.

transformation. This short form was produced by the deletion in the nucleotides encoding of the C-terminal part of the core domain, and it was expected that the deletion could cause a frame shift, possibly generating a p53 molecule with a different C-terminal domain (Fig. 2). The C-terminal domains of p53 contains the nuclear localization signals [25], the p53 oligomerization domain [27] and a domain mediating the non-sequence-specific interaction of p53 with DNA and RNA [29]. In addition, these domains represents the major regulatory domain of the p53 molecule, modulating sequence-specific DNA binding of central core domain of p53 [8], and contains several phosphorylation sites by cellular kinases [17]. The biological significance of this short form of $p 53$ transcript still remains to be established since we also confirmed that both intact and short forms of the $p 53$ transcript are present in each of these two cell lines. However, the amount of the intact p53 transcript was very low in these tumor cell lines, and it is possible that the short form of p53 may have different function(s) from intact p53 if this protein is expressed in tumors.

Mutations or deletion in the p53 transcript may be caused by viral protein(s) of MDV, or the deletion may result from alternative splicing which might be dependent on cell cycle progression [13]. MSB1 and MTB1, from which the short form of cDNA was recovered, originate from primary $\mathrm{T}$ cell lymphoma and are not transplantable, while other MD cell lines are derived from chickens transplanted with tumor cells. Thus, MSB1 and MTB1 cell lines are more similar to MD tumors in vivo, and the short form p53 mRNA could be involved in transformation in vivo by MDV. It also should be noted that this short form was not detected in the tumors obtained from chickens experimentally infected with MDV. This finding suggests that this short form may not be necessary for the initiation of transformation by MDV, but may be important for maintenance of the early stage of transformation by MDV. To confirm the fact that chicken lymphoblastoid cell lines possess the mutations and deletion in the $p 53$ transcript, the genomic structure and mRNA of the coding region of $p 53$ gene in many chicken tumors should be studied. The short form of p53 transcript might contribute to tumor formation through the regulation of cell growth, and to study the deletion mechanism of the $p 53$ transcript would be important to obtain information on the transformation process by MDV.

ACKNOWLEDGMENT. This work was supported by Research Fellowship of the Japan Society for the Promotion of Science.

\section{REFERENCES}

1. Akiyama, Y. and Kato, S. 1974. Two cell lines from lymphomas of Marek's disease. Biken J. 17: 105-116.

2. Brunovskis, P., Qian, Z., Li, D., Lee, L. F. and Kung, H-J. 1996. Functional analysis of the MDV basic-leucine zipper product, meq. pp. 265-270. In: Current Research on Marek's 


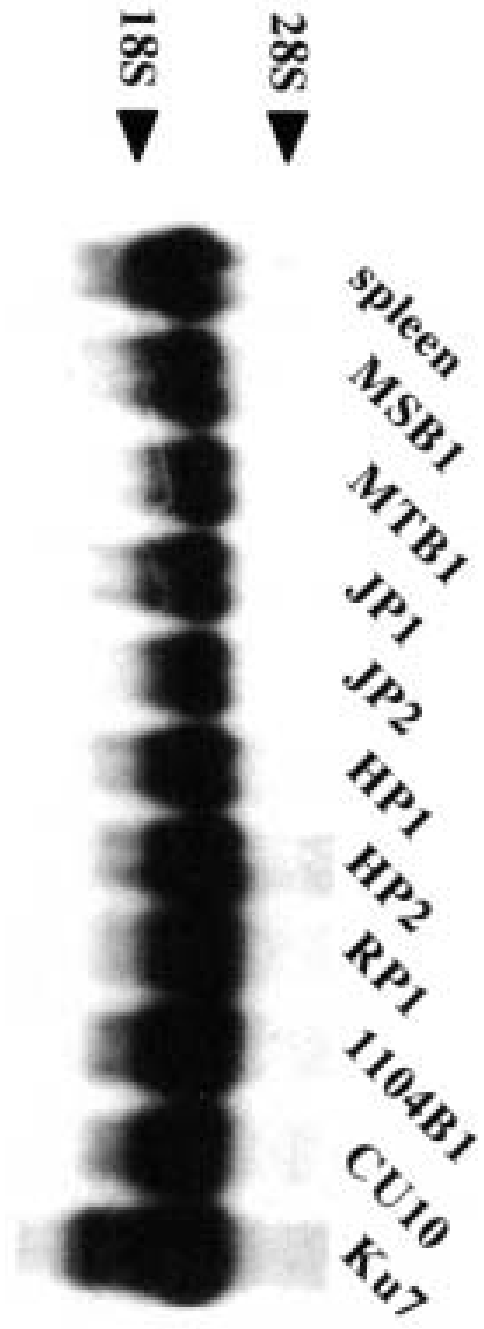

Fig. 3. Northern blot analysis of $p 53$ transcripts expressed in tumor cell lines. Total RNA samples prepared from Marek's disease (MSB1, MTB1, JP1, JP2, HP1, HP2 and RP1), avian leukosis (1104B1 and CU10) and reticuloendotheliosis $(\mathrm{Ku} 7)$ tumor cell lines were analyzed. Arrow heads indicates the positions of $p 53$ transcripts, $18 \mathrm{~S}$ and $28 \mathrm{~S}$ ribosomal RNAs.

Disease (Silva, R.F., Cheng, H.H., Coussens P.M., Lee, L.F. and Velicer, L.F. eds.), American Association of Avian Pathologists, Kennett Square.

3. Calnek, B.W., Murthy, K.K. and Schat, K.A. 1978. Establishment of Marek's disease lymphoblastoid cell lines from transplantable versus primary lymphoma. Int. J. Cancer 21: 100-107.

4. El-Deiry, W. S., Kern, S. E., Pietenpol, J. A., Kinzler, K. W.

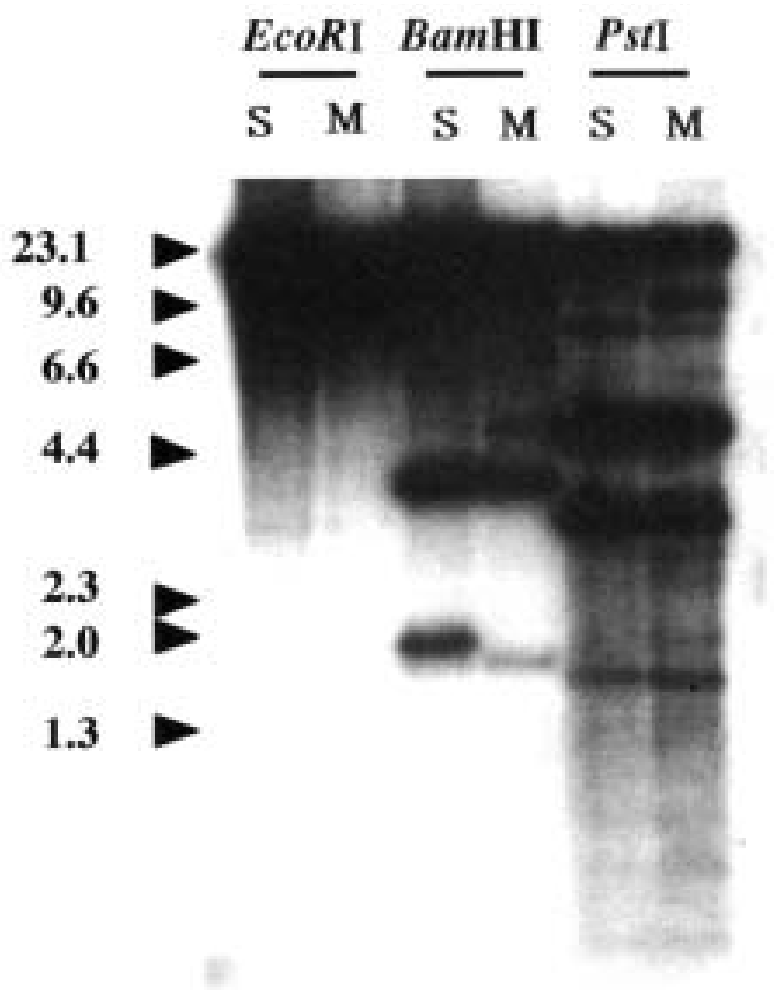

Fig. 4. Southern blot analysis of the chicken $p 53$ gene. Cellular DNA samples were prepared from MSB-1 (M) and normal splenocytes (S). These DNA samples were digested with either EcoRI, BamHI or PstI, fractionated on a agarose gel, and transferred to a membrane filter. Then, the filter was probed with a $p 53$-specific probe. Numbers and arrow heads indicate the sizes $(\mathrm{kb})$ and locations of molecular standard markers.

and Vogelstein, B. 1992. Definition of a consensus binding site for p53. Nature Genetics 1: 45-49.

5. Finlay, C.A., Hinds, P. W. and Levine, A. J. 1989. The $p 53$ proto-oncogene can act as a suppressor of transformation. Cell 57: 1083-1093.

6. Hihara, H., Shimizu, T. and Yamamoto, H. 1974. Establishment of tumor cell lines cultured from chickens with avian lymphoid leukosis. Natl. Inst. Anim. Health Q. 14: 163-173.

7. Hollstein, M., Sidransky, D., Vogelstein, B. and Harris, C. C. 1991. p53 mutations in human cancers. Science 253: 49-53.

8. Hupp, T.R., Meek, D. W., Midgley, C. A. and Lane, D.P. 1992. Regulation of the specific DNA binding function of p53. Cell 71: 875-886.

9. Ikuta, K., Nakajima, K., Kanamori, A., Maotani, K., Mah, J.S., Ueda, S., Kato, S., Yoshida, M., Nii, S., Naito, M., Nishida-Umehara, C., Sasaki, M. and Hirai, K. 1985. Establishment and characterization of a T-lymphoblastoid cell line MDCC-MTB1 derived from chicken lymphocytes infected in vitro with Marek's disease virus serotype I. Int. J. Cancer 39: 514-520.

10. Kastan, M.B., Zhan, Q., El-Deiry, W. S., Carrier, F., Jacks, T., Walsh, W. V., Plunkett, B. S., Vogelstein, B. and Fornace, A. J. Jr. 1992. A mammalian cell cycle checkpoint pathway utilizing p53 and GADD45 is defective in ataxia-telangiectasia. Cell 71: 587-597. 
11. Kern, S. E., Pietenpol, J. A., Thiagalingam, S., Seymour, A., Kinzler, K. W. and Vogelstein, B. 1992. Oncogenic form of p53 inhibit p53-regulated gene expression. Science 256: 827830.

12. Komori, H., Ishiguro, N., Horiuchi, M., Shinagawa, M. and Aida, Y. 1996. Predominant $p 53$ mutations in enzootic bovine leukemic cell lines. Vet. Immunol. Immunopathol. 52: 53-63.

13. Kulesz-Martin, M.F., Lisafeld, B., Huang, H., Kisiel, N. D. and Lee L. 1994. Endogenous p53 protein generated from wild type alternatively spliced $p 53$ RNA in mouse epidermal cells. Mol. Cell. Biol. 14: 1698-1708.

14. Lane, D.P. 1992. p53, guardian of the genome. Nature (Lond.) 358: $15-16$.

15. Lane, D.P. and Crawford, L.V. 1979. T antigen is bound to a host protein in SV40-transformed cells. Nature (Lond.) 278: 261-263.

16. Mayr, B., Heczko, U., Schellander, K., Schleger, W. and Reifinger, M. 1994. Sequence of an exon of the canine $p 53$ gene-mutation in a papilloma. Br. Vet. J. 150: 81-84.

17. Meek, D. W. 1994. Post-translational modification of $\mathrm{p} 53$. Cancer Biol. 5: 203-210.

18. Nazerian, K., Stephens, E. A., Sharma, J. M., Lee, L. F., Gailitis, M. and Witter, R. L. 1976. A nonproducer T lymphoblastoid cell line from Marek's disease transplantable tumor (JMV). Avian Dis. 21: 69-76.

19. Nigro, J. M., Baker, S. J., Presinger, A. C., Jessup, J. M., Hostetter, R., Cleary, K., Bigner, S. H., Davidson, N., Baylin, S., Devilee, P., Glover, T., Collins, F. S., Weston, A., Modali, R., Harris, C C. and Vogelstein, B. 1989. p53 gene mutations occur in diverse human tumor types. Nature (Lond.) 342: 705-708.

20. Powell, P. C., Payne, L. N., Frazier, J. A. and Rennie, M. 1974. T lymphoblastoid cell lines from Marek's disease lymphomas. Nature (Lond.) 251: 79-80.

21. Sarnow, P., Ho, Y. S., Williams, J. and Levine, A. J. 1982. Adenovirus E16-58kd tumor antigen and SV40 large tumor antigen are physically associated with the same $54 \mathrm{kd}$ cellular protein in transformed cells. Cell 28: 387-394.

22. Sasaki, T., Koyama, H., Yoshikawa, H. and Sasahara, J. 1981. Establishment of tumor cell lines cultured from chick embryos and chickens inoculated with oncogenic reticuloendotheliosis virus. p. 170. In: Proceedings of the 92nd Meeting of the Japanese Society for Veterinary Science.

23. Schat, K. A. 1987. Marek's disease: a model for protection against herpesvirus-induced tumors. Cancer Surv. 6: 1-37.

24. Scheffner, M., Werness, B. A., Huibregtse, J. M., Levine, A. J. and Howley, P. M. 1990. The E6 oncoprotein encoded by human papillomavirus types 16 and 18 promotes the degradation of p53. Cell 63: 1129-1136.

25. Shaulsky, G., Ben-Ze'ev, A. and Rotter, V. 1990. Subcellular distribution of the p53 protein during the cell cycle of Balb/c 3 T3 cells. Oncogene 5: 1707-1711.

26. Soussi, T., Caron de Fromentel, C. and May, P. 1990. Structural aspects of the p53 protein in relation to gene evolution. Oncogene 5: 945-952.

27. Sturzbecher, H.-W., Brain, R., Addison, C., Rudge, K., Remm, M., Grimaldi, M. and Keenan, E. 1992. A C-terminal Éøhelix plus basic region motif is the major structural determinant of p53 tetramerization. Oncogene 7: 1513-1523.

28. Wang, X. W., Forrester, K., Yeh, H., Feitelson, M. A. and Gu, J-R. 1994. Hepatitis B virus X protein inhibits p53 sequence-specific DNA binding, transcriptional activity, and association with transcription factor ERCC3. Proc. Natl. Acad. Sci. U.S.A. 91: 2230-2234.

29. Wang, Y., Reed, M., Wang, P., Stenger, J. E., Mayr, G., Anderson, M. E., Schwedes, J. F. and Tegtmeyer, P. 1993. p53 domains: identification and characterization of two autonomous DNA-binding regions. Genes Dev. 7: 2575-2586.

30. Xie, Q., Anderson, A. S. and Morgan, R. W. 1996. Marek's disease virus (MDV) ICP4, pp38, and meq genes are involved in the maintenance of transformation of MDCC-MSB1 MDV-transformed lymphoblastoid cells. J. Virol. 70: 11251131.

31. Yamaguchi, S., Kawamura, H., Matsuda, H. and Kato, S. 1979. Establishment of Marek's disease lymphoblastoid cell lines from chickens with BABK of B blood groups. Biken $J$. 22: $35-40$.

32. Yew, P. R. and Berk, A. J. 1992. Inhibition of p53 transactivation required for transformation by adenovirus early 1B protein. Nature (Lond.) 357: 82-85.

33. Yin, Y., Tainsky, M. A., Bischoff, F. Z., Strong, L. C. and Wahl, G. M. 1992. Wild-type p53 restores cell cycle control and inhibits gene amplification in cell with mutant $p 53$ alleles. Cell 70: 937-948.

34. Yonish-Rouach, E., Resnitzky, D., Lotem, J., Sachs, L., Kimchi, A. and Oren, M. 1991. Wild-type p53 induces apoptosis of myeloid leukemic cells that is inhibited by interleukin-6. Nature (Lond.) 352: 345-347. 